\title{
Antitumor activity of the Ailanthus altissima bark phytochemical ailanthone against breast cancer MCF-7 cells
}

\author{
RUXING WANG ${ }^{1,2}$, YANJIE LU ${ }^{3}$, HONG LI ${ }^{4}$, LIXIN SUN ${ }^{4}$, NING YANG ${ }^{4}$, \\ MINGZHEN ZHAO ${ }^{4}$, MANLI ZHANG ${ }^{1}$ and QINGWEN SHI $^{1}$
}

\begin{abstract}
${ }^{1}$ Department of Medicinal Natural Product Chemistry, School of Pharmaceutical Sciences, Hebei Medical University, Shijiazhuang, Hebei 050017; ${ }^{2}$ Hebei Province Key Laboratory of Research and Development for Chinese Medicine, Institute of Chinese Materia Medica; ${ }^{3}$ Department of Pathology, Institute of Cancer Research, Chengde Medical College; ${ }^{4}$ Department of Central Laboratory, The Affiliated Hospital of Chengde Medical College, Chengde, Hebei 067000, P.R. China
\end{abstract}

Received March 18, 2016; Accepted November 16, 2017

DOI: $10.3892 / 01.2018 .8039$

\begin{abstract}
Ailanthone is isolated from the bark of Ailanthus altissima (Mill.) Swingle (Simaroubaceae). The mechanism that underlies the activity of ailanthone on MCF-7 cells was investigated by MTT assay. Breast cancer MCF-7 cells were treated with $0.5,1.0,2.0,4.0$ and $8.0 \mu \mathrm{g} / \mathrm{ml}$ ailanthone for 24 , 48 and $72 \mathrm{~h}$. The inhibition of proliferation induced by treatment with ailanthone was assessed by MTT assay. Apoptosis and cell cycle distribution in MCF-7 cells with the same doses of ailanthone for $48 \mathrm{~h}$ were determined by flow cytometry. Expression of apoptosis-associated genes and proteins were analyzed by reverse transcription-polymerase chain reaction (RT-PCR) and western blot analysis, respectively. The results revealed that ailanthone inhibited MCF-7 cell proliferation. Flow cytometry assay demonstrated that ailanthone induced apoptosis and $\mathrm{G}_{0} / \mathrm{G}_{1}$ cell cycle arrest in MCF-7 cells. Western blotting and RT-PCR assays demonstrated that upregulation of pro-apoptotic caspase- 3 and Bcl-associated $\mathrm{X}$, and downregulation of anti-apoptotic apoptosis regulator B-cell lymphoma-2 in MCF-7 cells may be associated with the induction of apoptosis and inhibition of proliferation. To the best of our knowledge, the present study is the first to investigate the antitumor activity of ailanthone from A. altissima on MCF-7 cells and to attempt to elucidate the underlying mechanism. The present study revealed the presence of ailanthone-mediated antitumor effects, indicating that ailanthone may be a novel phytomedicine with potential use in breast cancer therapy.
\end{abstract}

Correspondence to: Dr Qingwen Shi, Department of Medicinal Natural Product Chemistry, School of Pharmaceutical Sciences, Hebei Medical University, 361 Zhong Shan East Road, Shijiazhuang, Hebei 050017, P.R. China

E-mail: 1716023668@qq.com

Key words: quassinoid, breast cancer, inhibition of proliferation, apoptosis, cell cycle

\section{Introduction}

Breast cancer is one of the most common cancers and the leading cause of cancer-associated mortality among women, causing significant morbidity worldwide (1). Nearly 5.8/100,000 new breast cancer cases are diagnosed in developed countries and $>10.5$ new breast cancer cases per 100,000 individuals occur worldwide each year (1). In the early stages of the disease, breast cancer, as in case of a number of other cancers, tends to spread asymptomatically throughout the body and at the point of diagnosis there is an increased likelihood of identification of metastatic lesions (2). Conventional therapies, including surgery, radiotherapy and chemotherapy, have served roles in treatment of breast cancer, but there remain numerous problems in tumor therapy. For example, cyclophosphamide, methotrexate and 5-fluorouracil chemotherapy for breast cancer have various side effects $(3,4)$.

Despite progress in anticancer therapeutics, there are few efficient drugs with low toxicity available to treat cancer. Plants have been previously used in cancer therapy (5). Traditional medical phytotherapy has been used for cancer treatment for several millennia in Asia, including in China, Japan and Thailand, and is currently being used for cancer prevention and therapy worldwide (6-8). Throughout the centuries, certain plant extracts have been tested for antitumor potential (9). Plants are a source of a number of effective anticancer agents in current use, including taxanes, irinotecan, topotecan, vincristine and vinblastine (10-12). Plant products such as these can aid in discovery and development of novel anticancer drugs. In addition, plant products demonstrate fewer side effects compared with chemical drugs. There has been an increasing interest in identifying and isolating natural compounds from medicinal plants with an aim to develop novel anticancer drugs (13).

Ailanthus altissima is an example of a plant that has been used in tumor therapy (14). A. altissima, which grows in Northeast and Central China, can also be present in Europe and the USA and has been used as a traditional Chinese medicine for a number of years (15). The bark of A. altissima has been used for the treatment of ascariasis, diarrhea, spermatorrhea, bleeding and gastrointestinal diseases in China (16). 
The antitumor effect that has enabled the use of this plant in the treatment of colonic, cervical, and rectal cancer has been previously described (17). In the present study, ailanthone was successfully isolated from A. altissima. Ailanthone has a wide spectrum of biological activities, including anti-allergic, anti-malarial, anti-HIV, anti-inflammatory, anti-ulcer and anti-microbial activities $(18,19)$. Ailanthone has been demonstrated to exhibit in vitro growth-inhibitory effects against several cancer cell lines, including HepG2, Hep3B, R-HepG2, HeLa and A549 cells $(18,20)$. Rosati (20) demonstrated that ailanthone could induce mitochondrial membrane depolarization and caspase-3 activation in Jurkat cancer cells. However, the antitumor activity in breast cancer treatment and the underlying molecular mechanism remain to be elucidated. In the present study, MCF-7 cells were used to evaluate the antitumor activity of ailanthone and the underlying molecular mechanism.

\section{Materials and methods}

Plant material and extraction. The bark of A. altissima (catalog no., NMC-2012-2) was purchased from Anguo Zhong Sheng Medicinal Material Co., Ltd. (Anguoshi, China). The bark of A. altissima was powdered, a 10-fold volume of methanol was added to the powdered sample and allowed to soak for $12 \mathrm{~h}$. Hot reflux was performed two times serially, each time using a rotary evaporator with $95 \%$ ethanol at $80^{\circ} \mathrm{C}$ for $2 \mathrm{~h}$, filtered, and the filtrate was merged. The combined filtrates were concentrated in vacuo, and then treated with saturated salt solution at concentration of $20 \%$. It was extracted with petroleum ether and dichloromethane for $2 \mathrm{~h}$, and dried in vacuo at $40^{\circ} \mathrm{C}$ respectively. The extract with was separated with 50 times the amount of 200-300 mesh silica gel column (Qingdao Haiyang Chemical Co., Ltd., Qingdao, China). The mobile phase was a solution of dichloromethane and methanol in ratios of 50:1, 30:1, 15:1, 10:1, 5:1, and $500 \mathrm{ml}$ was collected using each ratio. A total of 211 fractions were collected, and similar fractions were combined on the basis of TLC to obtain 35 major fractions. Following further purification by crystallization, ailanthone was purified as previously described (21).

Cell preparation. Breast cancer MCF-7 cells were purchased from Shanghai Institute of Biochemistry and Cell Biology (Shanghai, China), and grown in Dulbecco's Modified Eagle's medium (DMEM, Gibco; Thermo Fisher Scientific, Inc.). DMEM was supplemented with $100 \mu \mathrm{g} / \mathrm{ml}$ streptomycin, penicillin (Sigma-Aldrich; Merck KGaA, Darmstadt, Germany) and $10 \%$ (v/v) FBS (Gibco; Thermo Fisher Scientific, Inc.). Cells were cultured at $37^{\circ} \mathrm{C}$ and $5 \% \mathrm{CO}_{2}$ in a humidified environment.

Cell viability assay. Cell viability was assessed by MTT colorimetric assay (22). The cells were treated with various concentrations $(0.5,1.0,2.0,4.0$ and $8.0 \mu \mathrm{g} / \mathrm{ml})$ of ailanthone for 24, 48 and $72 \mathrm{~h}$. At the end of the treatment, $50 \mu \mathrm{l}$ MTT $(5 \mathrm{mg} / \mathrm{ml})$ was added to each well $\left(1 \times 10^{5}\right.$ cells $\left./ \mathrm{ml}\right)$ and the samples were incubated for an additional $1 \mathrm{~h}$. The culture medium was removed and dissolved by adding $100 \mu \mathrm{l}$ dimethyl sulfoxide. The absorbance was measured at a wavelength of $490 \mathrm{~nm}$.
Cell apoptosis. The level of cell apoptosis was determined by flow cytometry with annexin V (BD Biosciences, Franklin Lakes, NJ, USA) labeling and propidium iodide (PI) exclusion staining. MCF-7 cells were treated with 0.5, 1.0, 2.0, 4.0 and $8.0 \mu \mathrm{g} / \mathrm{ml}$ ailanthone for $48 \mathrm{~h}$, collected, washed with PBS and suspended in binding buffer (BD Biosciences). Subsequently, the cells $\left(1 \times 10^{5}\right.$ cells $\left./ \mathrm{ml}\right)$ were stained with $10 \mu \mathrm{l}$ annexin V-fluorescein FITC and $5 \mu \mathrm{l}$ PI, incubated in dark at room temperature for $15 \mathrm{~min}$ according to the manufacturer's protocol and subjected to flow cytometry using a flow cytometer (ModFit 6.0, BD Biosciences, USA). Cells undergoing apoptosis were stained with annexin $\mathrm{V}$ and treated as described above.

Cell cycle distribution. Cells were seeded at a density of $1 \times 10^{6} / \mathrm{ml}$ in 6 -well microplates and treated with $0.5,1.0,2.0$, 4.0 and $8.0 \mu \mathrm{g} / \mathrm{ml}$ ailanthone for $48 \mathrm{~h}$. A total of $1 \times 10^{5}$ cells were collected for each treatment, washed with PBS, trypsinized with $0.25 \%$ trypsin and harvested by centrifugation for $5 \mathrm{~min}$ at $70 \mathrm{x} \mathrm{g}$ at room temperature. Cells were re-suspended with $0.5 \mathrm{ml}$ PBS, fixed overnight with cold $70 \%$ ethanol at $-20^{\circ} \mathrm{C}$ and stained with PI solution containing $10 \mu \mathrm{g} / \mathrm{ml}$ RNase A and $50 \mu \mathrm{g} / \mathrm{ml}$ PI for $60 \mathrm{~min}$ at room temperature. Cells were analyzed by flow cytometry, as previously described (23).

Reverse transcription-polymerase chain reaction (RT-PCR) analysis. MCF-7 cells were treated by ailanthone $(0.5,1.0,2.0$, 4.0 and $8.0 \mu \mathrm{g} / \mathrm{ml}$ ), and following extraction of total cellular RNA from the MCF-7 cells using TRIzol reagent (Thermo Fisher Scientific, Inc., Waltham, MA, USA), $2 \mu \mathrm{g}$ of total RNA was reverse transcribed to generate cDNA using the PrimeScript RT reagent kit (Takara Bio, Inc.). The following thermocycling conditions were used for RT-PCR: Initial denaturation at $94^{\circ} \mathrm{C}$ for $30 \mathrm{sec}$, followed by 30 cycles of $94^{\circ} \mathrm{C}$ for $30 \mathrm{sec}, 56^{\circ} \mathrm{C}$ for $30 \mathrm{sec}$ and $72^{\circ} \mathrm{C}$ for $45 \mathrm{sec}$, and the final extension at $72^{\circ} \mathrm{C}$ for $8 \mathrm{~min}$. The PCR products were resolved in $2 \%$ agarose gels and visualized by staining with ethidium bromide (24). To semiquantify the PCR products, the bands representing the amplified products were analyzed by Quantity One analysis software (Bio-Rad Laboratories, Inc., Hercules, CA, USA). The relative level of the target mRNA expression was defined as the ratio of the absorbance of the target band to that of the $\beta$-actin band. The following primer sequences were used for PCR: (Takara RNA PCR Kit AMV, Ver.3.0) Caspase-3 (442 bp), forward 5'-ATCTCGGTCTGGTACAGA TGTCGAT-3' and reverse 5'-TGAATTTCGCCAAGAATA ATACCA-3'; Bcl-associated X (Bax; 258 bp), forward 5'-CAC CAGCTCTGAGCAGATCA-3', reverse 5'-ATGTCAGCTGCC ACTCGGA-3'; B-cell lymphoma 2 (Bcl-2; 383 bp), forward 5'-TACGAGTGGGATGCGGGAGATGT-3', reverse 5'-CCA CCGAACTCAAAGAAGGC-3'; GAPDH (135 bp), forward 5'-CAATGACCCCTTCATTGACC-3', reverse 5'-TGGAAG ATGGTGATGGGATT-3'.

Western blot analysis. MCF-7 cells were treated by ailanthone $(0.5,1.0,2.0,4.0$ and $8.0 \mu \mathrm{g} / \mathrm{ml})$, and lysed in lysis buffer [50 mmol/1 Tris- $\mathrm{HCl}$ (pH 8.0), $150 \mathrm{mmol} / 1 \mathrm{NaCl}, 0.5 \%$ NP40, $0.5 \%$ sodium deoxycholate, $0.1 \%$ SDS with protease inhibitor]. Determination of total protein content was performed using a BCA assay (Beijing Solarbio Science and Technology, Co., Ltd., Beijing China). The proteins were separated by $12 \%$ 
SDS-PAGE and transferred to polyvinylidene difluoride membranes. The membranes were blocked with $5 \%$ milk in Tris-buffered saline- $0.05 \%$ Tween-20 (TBST) for $3 \mathrm{~h}$ at room temperature. Following washing in TBST, the membranes were incubated for $2 \mathrm{~h}$ at room temperature with 1:1,000 dilutions of rabbit monoclonal antibodies for BCL-2, (cat no. 2872; Cell Signaling Technology, Inc., Danvers, MA, USA), Bax (cat no. 2772; Cell Signaling Technology, Inc.) and Caspase-3, (cat no. 9662; Cell Signaling Technology, Inc.), and a mouse monoclonal antibody for $\beta$-actin (ab8226; Abcam, Cambridge, UK). Following washing in TBST, the blots were incubated with horseradish peroxidase-conjugated goat anti-rabbit immunoglobulin G secondary antibody (rabbit monoclonal antibody; mouse monoclonal antibody, 1:3,000; Abcam) for $1 \mathrm{~h}$ at room temperature. The signal was detected using an ECL Western Blotting Substrate kit (Applygen Technologies, Inc., Beijing, China), and exposed to X-ray film at room temperature. Protein expression levels were quantitated using Quantity-one software (v 4.62; Bio-Rad Laboratories, Inc.).

Statistical analysis. SPSS software (version 16; SPSS, Inc., Chicago, IL, USA) was used for statistical analysis of the data. Data are presented as the mean \pm standard deviation. One-way analysis of variance followed by Dunnett's test was used for statistical analysis. $\mathrm{P}<0.05$ was considered to indicate a statistically significant difference.

\section{Results}

Inhibitory effect of ailanthone on proliferation of tumor cells. The effect of ailanthone on viability of MCF-7 cells was measured by MTT assay. Compared with the untreated control, the viability of MCF-7 cells treated with $0.5,1.0,2.0$, 4.0 or $8.0 \mu \mathrm{g} / \mathrm{ml}$ of ailanthone was $92.62,88.46,86.36,73.74$ and $64.05 \%$, respectively, following $24 \mathrm{~h}$ of treatment; 77.27 , $75.65,69.89,61.40$ and $52.40 \%$, respectively, following $48 \mathrm{~h}$ of treatment; and $64.36,62.48,57.64,50.24$ and $43.24 \%$, respectively, following $72 \mathrm{~h}$ of treatment (Fig. 1). The data indicated that ailanthone inhibits MCF-7 cell proliferation.

Effects of ailanthone on apoptosis of MCF-7 cells. Following $48 \mathrm{~h}$ of treatment with ailanthone, 22.28, 27.99, 35.88, 49.77 and $75.51 \%$ of cells were apoptotic at doses of $0.5,1.0,2.0,4.0$ and $8.0 \mu \mathrm{g} / \mathrm{ml}$, respectively (Fig. 2). In total, $2.13 \%$ of control cells were apoptotic at $48 \mathrm{~h}$, which is significantly different to all treatment groups $(\mathrm{P}<0.01)$.

Effects of ailanthone on cell cycle of MCF-7 cells. Following treatment with $0.5,1.0,2.0,4.0$ and $8.0 \mu \mathrm{g} / \mathrm{ml}$ ailanthone for $48 \mathrm{~h}$, all treatment groups exhibited statistically significant differences compared with the control. Following treatment with ailanthone, the proportion of cells in the $G_{0} / G_{1}$ phase increased and percentage of cells in $S$ and $G_{2} / M$ phases decreased significantly compared with the control group (Fig. 3).

Alteration of expression levels of Bcl-2 and Bax mRNA. Following $48 \mathrm{~h}$ of treatment with different doses of ailanthone, RT-qPCR demonstrated that in the MCF-7 cells, expression of the Bax and caspase- 3 genes increased, whereas expression

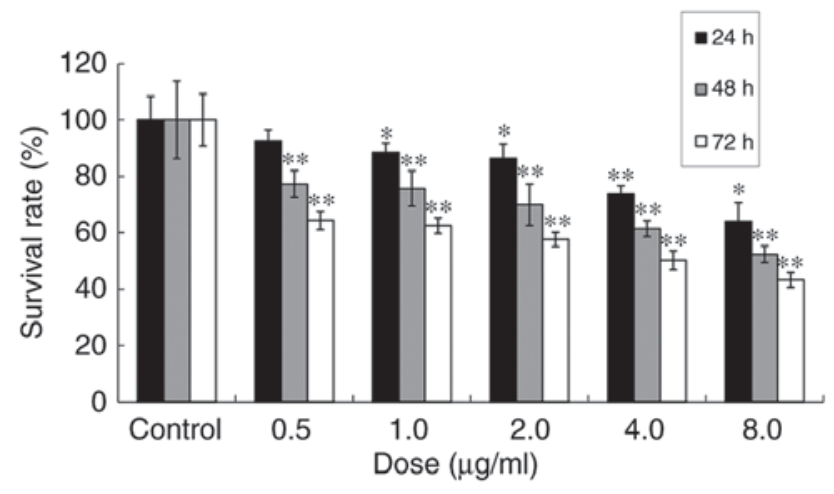

Figure 1. Effect of ailanthone on MCF-7 cell survival. Cells were treated with $0.5,1,2,4$ and $8 \mu \mathrm{g} / \mathrm{ml}$ ailanthone for 24,48 , and $72 \mathrm{~h}$. Cell survival was determined by MTT. Data are presented as the mean \pm standard deviation $(\mathrm{n}=3) .{ }^{*} \mathrm{P}<0.05$ and ${ }^{* *} \mathrm{P}<0.01$ vs. the respective control group.

levels of the Bcl-2 gene decreased. Doses of 1.0, 2.0, 4.0 and $8.0 \mu \mathrm{g} / \mathrm{ml}$ of ailanthone resulted in significantly altered expression, compared with the control group (Fig. 4).

Effects of ailanthone on protein expression levels by western blotting. Following $48 \mathrm{~h}$ of treatment with $0.5,1.0,2.0,4.0$ or $8.0 \mu \mathrm{g} / \mathrm{ml}$ ailanthone, it was observed that ailanthone promoted the expression of Bax and caspase- 3 proteins, whereas the expression of Bcl-2 protein was inhibited. The inhibitory effect on Bcl-2 protein expression increased with the increase of the doses $(\mathrm{P}<0.05)$. The $\mathrm{Bax} / \mathrm{Bcl}-2$ ratios were $0.27,0.53$, $0.56,0.80,0.93$ and 1.25 at dosages of $0,0.5,1.0,2.0,4.0$ and $8.0 \mu \mathrm{g} / \mathrm{ml}$, respectively, and thus increased following treatment with ailanthone in a dose-dependent manner (Fig. 5).

\section{Discussion}

Breast cancer is the primary cause of mortality among women in the world, according to statistics from 2009 (2). Currently, certain cytotoxic drugs are used for the treatment of breast cancer, including daunorubicin, doxorubicin, cisplatin and bleomycin (25). However, these agents are costly and have been demonstrated to induce several side effects, including emesis, anemia, myelosuppression and cellular resistance (3). Therefore, it is necessary to identify alternative drugs or therapies to minimize side effects (26). As a result, natural medicines that cause fewer side effects have been attracting substantial attention (27). Previous research has demonstrated that natural antitumor drugs may serve important roles in the future. A phytochemical study demonstrated the presence of quassinoids in A. altissima and these compounds have been previously demonstrated to exhibit potent antitumor properties (28). To the best of our knowledge, the present study is the first to report that ailanthone isolated from A. altissimahas inhibits proliferation of MCF-7 cells.

The majority of drugs achieve antitumor effects by inducing apoptosis in tumor cells (29). Cell cycle analysis is used to determine the distribution of cells in different phases of the cell cycle and enables investigation of tumor proliferation as opposed to apoptosis. There are three cell cycle regulation points in $G_{1}, S$ and $G_{2}$ phases, which can modulate cell cycle progression. Induction of tumor cell cycle arrest in $\mathrm{G}_{0} / \mathrm{G}_{1}$ 

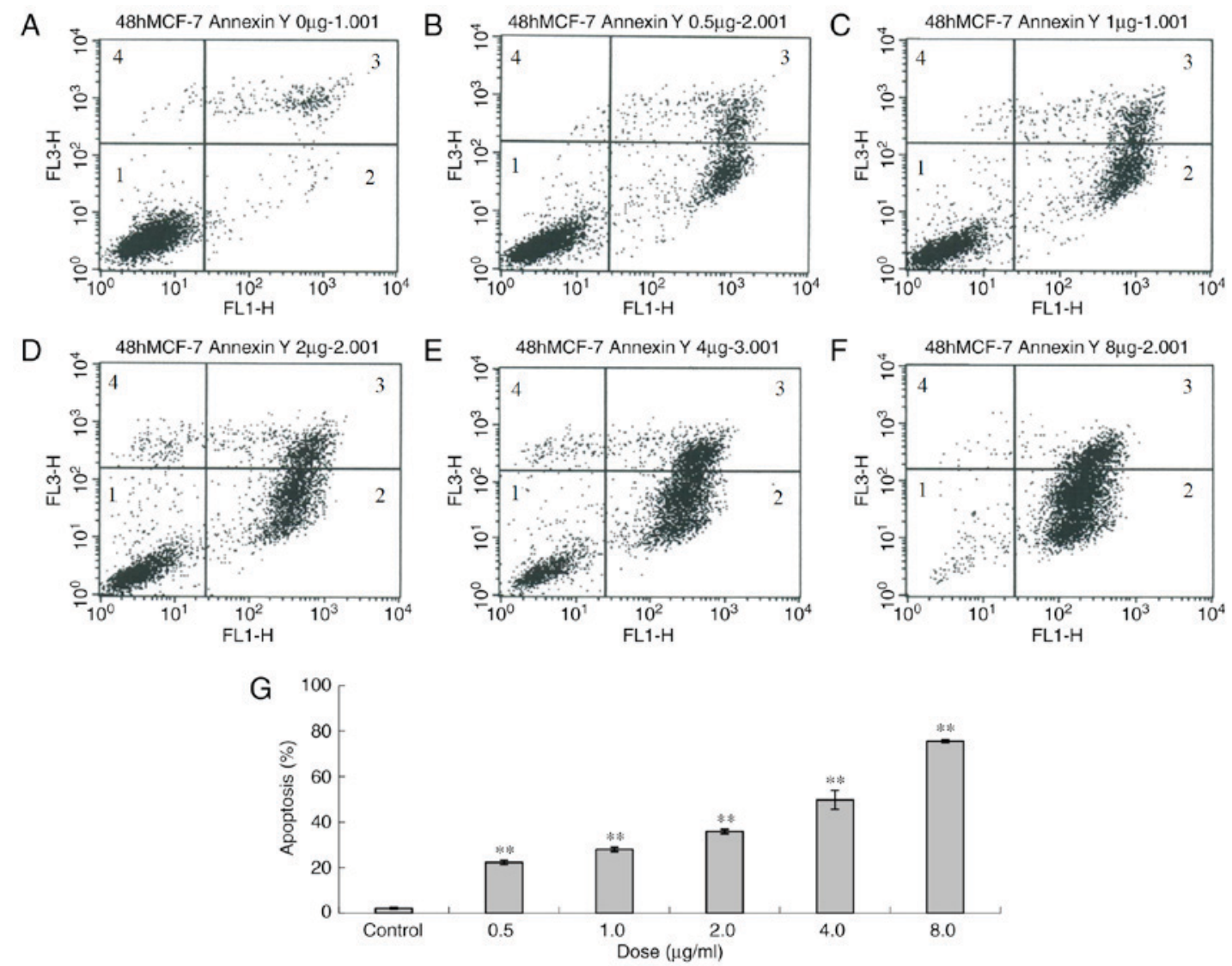

Figure 2. Apoptosis of MCF-7 cells following treatment with different doses of ailanthone $(0.5,1,2,4 \mathrm{and} 8 \mu \mathrm{g} / \mathrm{ml})$ for $48 \mathrm{~h}$, measured by flow cytometry. (A) Control (0 $\mu \mathrm{g} / \mathrm{ml}$ ) and (B) $0.5 \mu \mathrm{g} / \mathrm{ml}$, (C) $1.0 \mu \mathrm{g} / \mathrm{ml}$, (D) $2.0 \mu \mathrm{g} / \mathrm{ml}$, (E) $4.0 \mu \mathrm{g} / \mathrm{ml}$ and (F) $8.0 \mu \mathrm{g} / \mathrm{ml}$ ailanthone. (G) Histogram of apoptosis of MCF-7 cells Data are presented as the mean \pm standard deviation $(\mathrm{n}=3) .{ }^{* *} \mathrm{P}<0.01$ vs. the control and treatment groups. 1 , normal cells; 2 , early apoptosis; 3 , late apoptosis; 4 , dead cells.
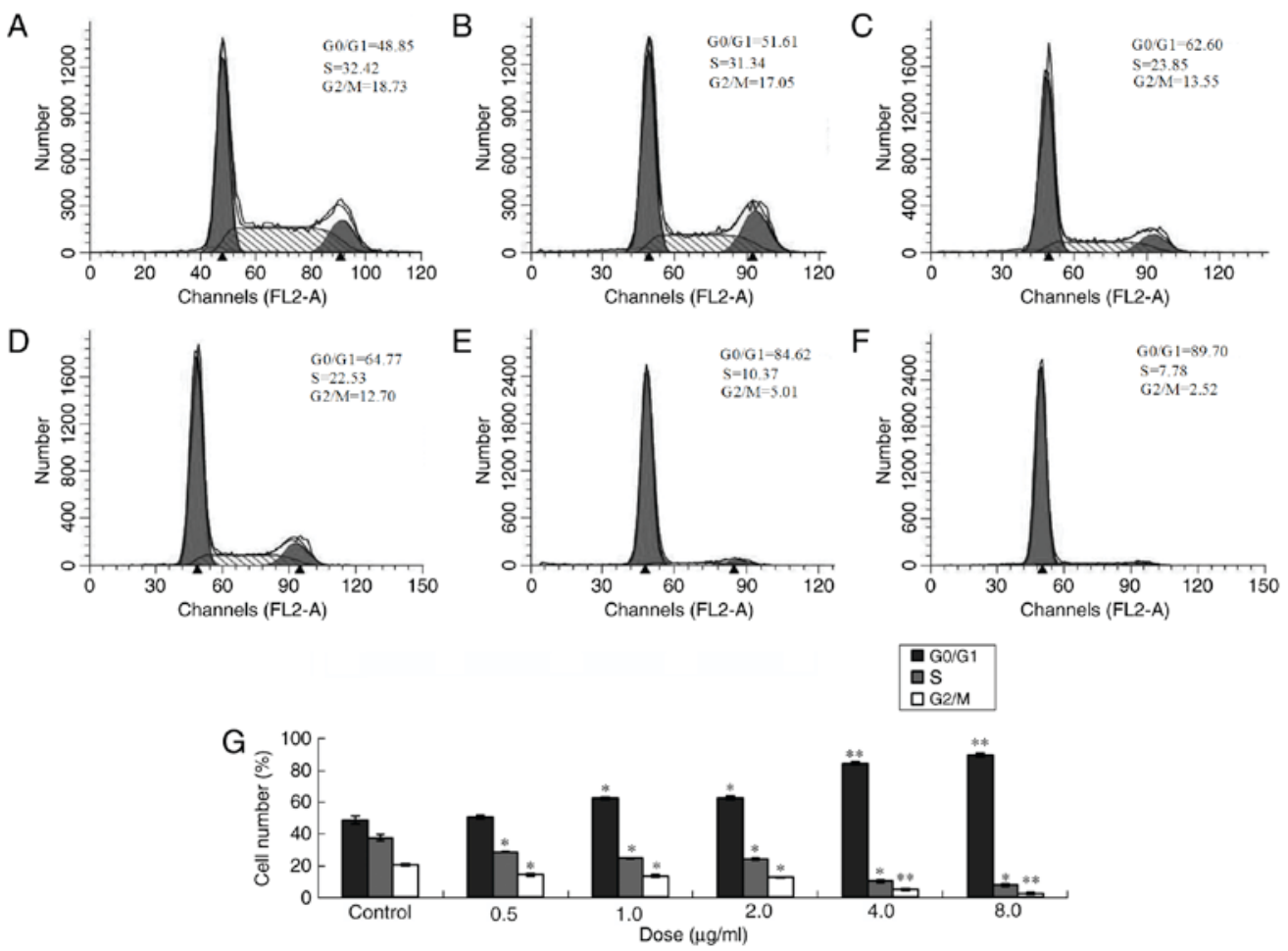

Figure 3. Cell cycle of MCF-7 cells following treatment with different doses of ailanthone. MCF-7 cells were treated with different doses of ailanthone for $48 \mathrm{~h}$ and the cell cycle distribution was measured by flow cytometry. (A) Control $(0 \mu \mathrm{g} / \mathrm{ml})$ and (B) $0.5 \mu \mathrm{g} / \mathrm{ml}$, (C) $1.0 \mu \mathrm{g} / \mathrm{ml}$, (D) $2.0 \mu \mathrm{g} / \mathrm{ml}$, (E) $4.0 \mu \mathrm{g} / \mathrm{ml}$ and (F) $8.0 \mu \mathrm{g} / \mathrm{ml}$ ailanthone. (G) Cell cycle distribution of MCF-7 cells. Data are presented as the mean \pm standard deviation ( $\mathrm{n}=3$ ). ${ }^{*} \mathrm{P}<0.05$ and ${ }^{* * *} \mathrm{P}<0.01 \mathrm{vs}$. the respective control group. 

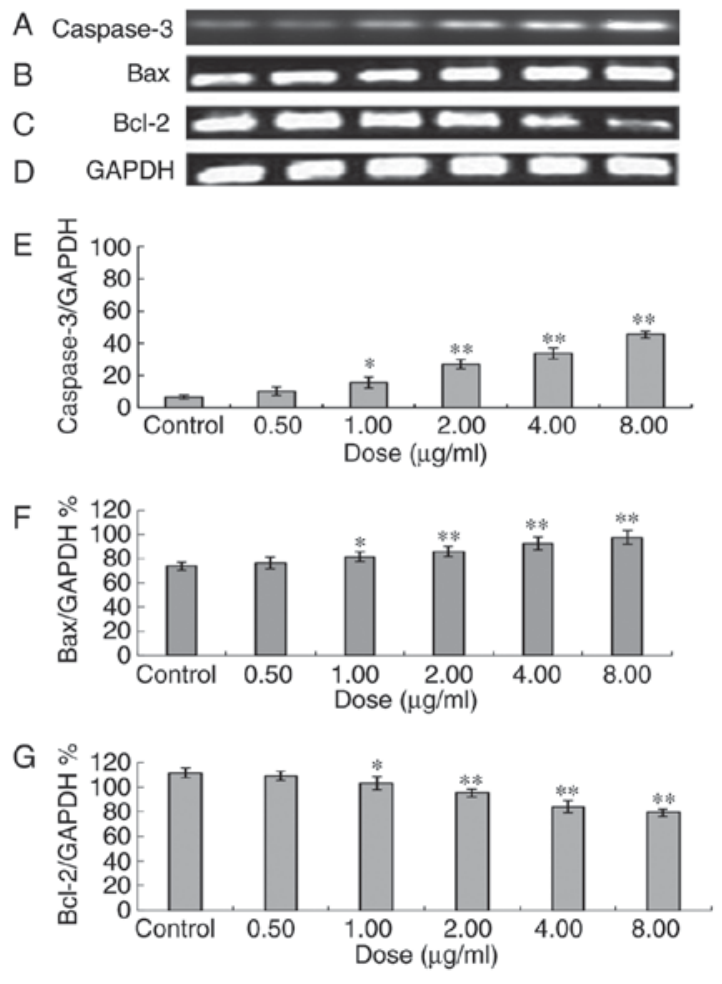

Figure 4. Caspase 3, Bax and Bcl-2 mRNA in MCF-7 cells following treatment with different doses of ailanthone. Following $48 \mathrm{~h}$ of treatment with ailanthone, levels of (A) caspase-3, (B) Bax, (C) Bcl-2 and (D) reference GAPDH mRNA in MCF-7 cells were measured by densitometric analysis of reverse transcription-polymerase chain reaction. Quantitative analysis of expression of (E) Caspase-3, (F) Bax and (G) Bcl-2. Data are presented as the mean \pm standard deviation $(\mathrm{n}=3)$. ${ }^{*} \mathrm{P}<0.05$ and ${ }^{* *} \mathrm{P}<0.01$ vs. the control group. Bcl-2, B-cell lymphoma-2; Bax, Bcl-associated X.

phase is a target for the development of antitumor therapy (30). Certain molecules, including tumor protein p53, serve a role in cell cycle inhibition and induction of apoptosis; cells may be arrested in the $G_{1}$ phase and apoptosis may be induced by p53 (31). In the present study, the results of flow cytometry revealed that, following treatment with ailanthone, apoptosis in MCF-7 cells increased. Analysis of the cell cycle by flow cytometry demonstrated an increase in the number of MCF-7 cells in $\mathrm{G}_{0} / \mathrm{G}_{1}$ phase following treatment with ailanthone and a decrease in the number of cells in $\mathrm{S}$ phase, indicating that the cells were arrested in the $G_{0} / G_{1}$ phase by so that the cells could not enter $\mathrm{S}$ phase or perform DNA synthesis, thus inhibiting proliferation. This checkpoint may be involved in the effects of ailanthone on the cell cycle of MCF-7 cells (32), but this potential mechanism remains to be further investigated. Caspases are mediators of apoptosis, of which caspase- 3 are frequently activated death protease that catalyzes specific cleavage of numerous cellular proteins (33). Tumor inhibition and apoptosis, as well as the expression of caspase-3, Bcl-2 and Bax were determined by flow cytometry. The results demonstrated that ailanthone can induce apoptosis in tumor cells. Apoptosis is an active cell suicide process that is regulated by p53 (34). The effect of Bcl-2 depends on the ratio of its expression with Bax; this ratio determines whether cells undergo apoptosis or survival upon signal stimulation (35). Excessive Bax expression in cells promotes apoptosis, whereas excessive Bcl-2 expression promotes survival (36).
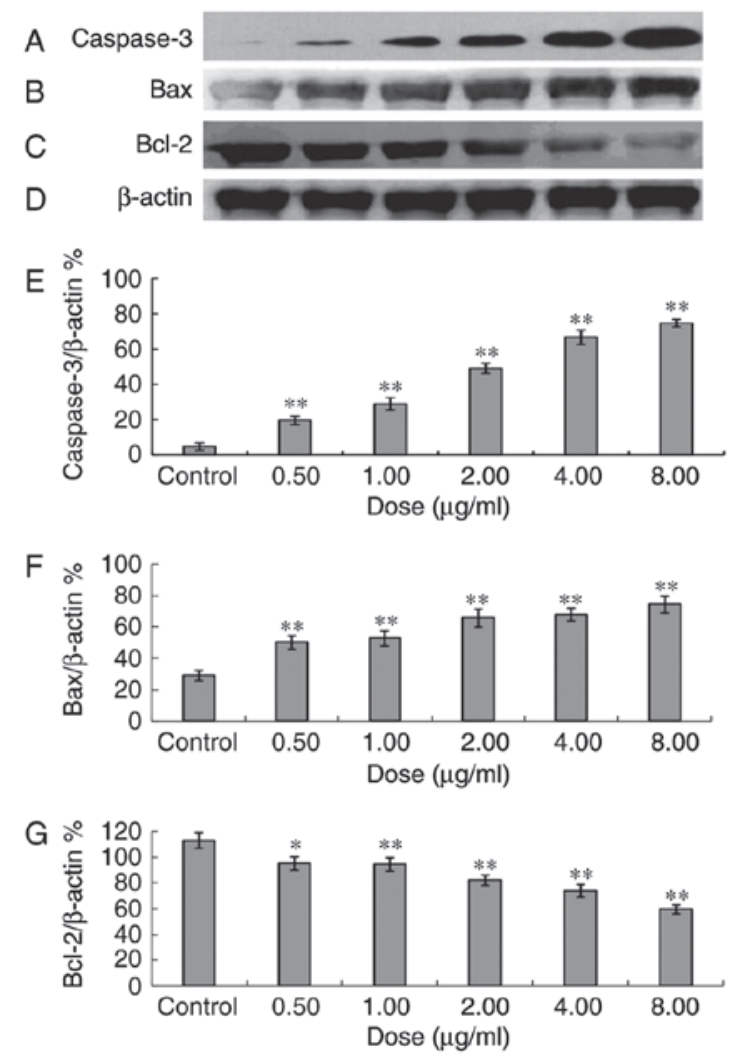

Figure 5. Caspase-3, Bax and Bcl-2 proteins in MCF-7 cells following intervention with different doses of ailanthone. Following $48 \mathrm{~h}$ of treatment with different doses of ailanthone, protein expression levels of (A) caspase 3, (B) Bax, (C) Bcl-2 and (D) $\beta$-actin in the MCF-7 cells were measured by western blotting. (E) Quantitative analysis of protein expression levels of caspase-3, (F) Bax and (G) Bcl-2. Data are presented as the mean \pm standard deviation $(n=3)$. ${ }^{*} \mathrm{P}<0.05$ and ${ }^{* *} \mathrm{P}<0.01$ vs. the control group. $\mathrm{Bcl}-2$, B-cell lymphoma-2; Bax, Bcl-associated X.

Western blot analysis was used to detect levels of Bax and Bcl-2 protein expression; it was demonstrated that following treatment of MCF-7 cells with $0.5,1.0,2.0,4.0$ or $8.0 \mu \mathrm{g} / \mathrm{ml}$ ailanthone for $48 \mathrm{~h}$, Bax expression increased, whereas that of Bcl-2 decreased markedly. The results indicated that the mechanism underlying ailanthone-induced MCF-7 cell apoptosis may be associated with the adjusting of the Bax and Bcl-2 family proteins. Experimental results demonstrated that ailanthone exhibited an inhibitory effect on cellular proliferation and induced apoptosis. The promotion of Bax and the inhibition of $\mathrm{Bcl}-2$ proteins may further enhance the antitumor effect.

Genetic abnormalities in the phosphatidylinositol 3-kinase $(\mathrm{PI} 3 \mathrm{~K}) / \mathrm{RAC}$ serine/threonine-protein kinase (AKT) signaling pathway are frequently observed in human tumors; previous studies indicate that this pathway is involved in the development of multiple cancer types (37). The role of the PI3K/AKT pathway and its potential as a therapeutic target for tumor treatment has been investigated in preclinical studies into a number of tumor types, including lung, breast and renal cancer, neuroblastoma and glioblastoma. The results of these studies indicate that the PI3K/AKT signaling pathway and those downstream of it are potential targets for therapeutic intervention (38-41). The PI3K/AKT pathway serves a role in apoptosis, cell cycle progression and tumorigenesis; therefore, we hypothesize that ailanthone-induced apoptosis may also involve the PI3K/AKT 
pathway, demonstrating that the ailanthone treatment of Huh7 cells resulted in a decrease in the expression of PI3K and AKT phosphorylation at threonine-408 and serine- 473 .

Treatment of MCF-7 cells with ailanthone resulted in cell apoptosis. In the present study, the antitumor effect of ailanthone indicated that this compound may be beneficial for the treatment of breast cancer. Further investigation is required to identify the mechanism underlying the antitumor activity.

In conclusion, the present study demonstrated that ailanthone, isolated from A. altissima, exhibited an inhibitory effect on MCF-7 cells and promoted cell apoptosis by upregulating Bax protein and mRNA. Ailanthone inhibited the protein and mRNA expression of $\mathrm{Bcl}-2$, indicating that is has potential antitumor activity. Ailanthone may be a novel phytomedicine for tumor therapy.

\section{Acknowledgements}

The authors would like to thank Professor Jun-Qing Liang (Shijiazhuang Yiling Pharmaceutical Co., Ltd., Hebei, China) for providing necessary facilities to perform experiments in the present study. The present study was supported by the National Natural Science Foundation of China (grant no., 81302664 and 81703001) and the Hebei Medical University Development Project (2016-kyfz111). We are grateful for the key discipline construction project of the Universities in Hebei (ZD 2017003); Chengde medical college high level talent research startup fund (201705) and Key Discipline Construction Projects of Higher Schools in Hebei. The authors also wish to extend thanks for the financial support of Syngenta Ltd. (2017-Hebei Medical University-Syngenta-04).

\section{Competing interests}

The authors declare that they have no competing interests.

\section{References}

1. Khoobchandani M, Ojeswi BK, Sharma B and Srivastava MM: Chenopodium album prevents progression of cell growth and enhances cell toxicity in human breast cancer cell lines. Oxid Med Cell Longev 2: 160-165, 2009.

2. Tokgun O, Akca H, Mammadov R, Aykurt C and Deniz G: Convolvulus galaticus, crocus antalyensis, and lilium candidum extracts show their antitumor activity through induction of p53-mediated apoptosis on human breast cancer cell line MCF-7 Cells. J Med Food 11: 1000-1005, 2012.

3. Binkley JM, Harris SR, Levangie PK, Pearl M, Guglielmino J, Kraus V and Rowden D: Patient perspectives on breast cancer treatment side effects and the prospective surveillance model for physical rehabilitation for women with breast cancer. Cancer 8 2207-2216, 2012.

4. Sitzia J and Huggins L: Side effects of cyclophosphamide, methotrexate, and 5 -fluorouracil (CMF) chemotherapy for breast cancer. Cancer Pract 6: 13-21, 1998.

5. da Rocha AB, Lopes RM and Schwartsmann G: Natural products in anticancer therapy. Curr Opin Pharmacol 1: 364-369, 2001.

6. Efferth T, Li PC, Konkimalla VS and Kaina B: From traditional Chinese medicine to rational cancer therapy. Trends Mol Med 13: 353-361, 2007.

7. Olaku O and White JD: Herbal therapy use by cancer patients: A literature review on case reports. Eur J Cancer 47: 508-514, 2011.

8. Dennis T, Fanous M and Mousa S: Natural products for chemopreventive and adjunctive therapy in oncologic disease. Nutr Cancer 61: 587-597, 2009.

9. Ho JW, Leung YK and Chan CP: Herbal medicine in the treatment of cancer. Curr Med Chem Anticancer Agents 2: 209-214, 2002.
10. Pezzuto JM: Plant-derived anticancer agents. Biochem Pharmacol 53: 121-133, 1997.

11. Kinghorn AD, Farnsworth NR, Doel Soejarto D, Cordell GA, Pezzuto JM, Udeani GO, Wani MC, Wall ME, Navarro HA, Kramer RA, et al: Novel strategies for the discovery of plant-derived anticancer agents. Pure Appl Chem 71: 611-618, 1999.

12. Lee KH: Anticancer drug design based on plant-derived natural products. J Biomed Sci 6: 236-250, 1999.

13. Bishayee A: Editorial: Current advances in cancer prevention and treatment by natural products. Curr Pharm Biotechnol 13: 115-116, 2012.

14. Efferth T, Li PC, Konkimalla VS and Kaina B: From traditional Chinese edicine to rational cancer therapy. Trends Mol Med 13: 353-361, 2007.

15. De Feo V, De Martino L, Quaranta E and Pizza C: Isolation of phytotoxic compounds from tree-of-heaven (Ailanthus altissima swingle). J Agric Food Chem 51: 1177-1180, 2003.

16. Rahman S, Fukamiya N, Ohno N, Tokuda H, Nishino H, Tagahara K, Lee KH and Okano M: Inhibitory effects of quassinoid derivatives on Epstein-Barr virus early antigen activation. Chem Pharm Bull (Tokyo) 45: 675-677, 1997.

17. Wang Y, Wang WJ, Su C, Zhang DM, Xu LP, He RR, Wang L, Zhang J, Zhang XQ and Ye WC: Cytotoxic quassinoids from Ailanthus altissima. Bioorg Med Chem Lett 23: 654-657, 2013.

18. Okunade AL, Bikoff RE, Casper SJ, Oksman A, Goldberg DE and Lewis WH: Antiplasmodial activity of extracts and quassinoids isolated from seedlings of Ailanthus altissima (Simaroubaceae). Phytother Res 17: 675-677, 2003.

19. Kundu P and Laskar S: A brief resume on the genus Ailanthus: chemical and pharmacological aspects. Phytochem Rev 9: 379-412, 2010.

20. Rosati A, Quarantam E, Ammirante M, Turco MC, Leone A and De Feo V: Quassinoids can induce mitochondrial membrane depolarisation and caspase 3 activation in human cells. Cell Death Differ 11 (Suppl 2): S216-S218, 2004.

21. Casinovi CG, Ceccherelli P, Grandolini G and Bellavita V: On the structure of ailanthone. Tetrahedron Lett 5: 3991-3997, 1964.

22. Bishayee A, Háznagy Radnai E, Mbimba T, Sipos P, Morazzoni P, Darvesh AS, Bhatia D and Hohmann J: Anthocyaninrich black current extract suppresses the growth of human hepatocellular carcinoma cells. Nat Pred Commun 5: 1613-1618, 2010.

23. Kim MJ, Kim YJ, Park HJ, Chung JH, Leem KH and Kim HK: Apoptotic effect of red wine polyphenols on human colon cancer SNU-C4cells. Food Chem Toxicol 44: 898-902, 2006.

24. Lu YJ, Xu Q, Chen L, Zuo Y, Liu S, Hu Y, Li X, Li Y and Zhao X: Expression of semaphorin 6D and its receptor plexin-A1 in gastric cancer and their association with tumor angiogenesis. Oncology 12: 3967-3974, 2016.

25. Moysich KB, Beehler GP, Zirpoli G, Choi JY and Baker JA: Use of common medications and breast cancer risk. Cancer Epidemiol Biomarkers Prev 7: 1564-1595, 2008.

26. Kim DW, Hong GH, Lee HH, Choi SH, Chun BG, Won CK, Hwang IK and Won MH: Effect of colloidal silver against the cytotoxicity of hydrogen peroxide and naphthazarin on primary cultured cortical astrocytes. Int J Neurosci 117: 387-400, 2007.

27. Duan JA, Su SL and Qian DW: Approaches and advances in the resources chemistry of Chinese medicinal material. Chin J Nat Med 7: 333-340, 2009.

28. Zhuo Z, Hu J, Yang X, Chen M, Lei X, Deng L, Yao N, Peng Q, Chen Z, Ye W and Zhang D: Ailanthone inhibits Huh7 cancer cell growth via cell cycle arrest and apoptosis in vitro and in vivo. Sci Rep 5: 16185, 2015.

29. James BR and Griffith TS: Activation of systemic antitumor immunity via TRAIL-induced apoptosis. OncoImmunology 17: 1178-1180, 2012.

30. Chen $\mathrm{M}, \mathrm{Xu} X Y, X \mathrm{D}$, et al: Inhibiting Bcl-2 gene expression enhance radiosensitivity of non-small cell lung cancer NCI-H460 cells. China Oncology 20: 641-5, 2010.

31. Bai X, Che F, Li J, Ma Y, Zhou Y, Zhai J and Meng L: Effects of adenovirus-mediated p16 and p53 genes transfer on apoptosis and cell cycle of lung carcinoma cells. Zhonghua Bing Li Xue Za Zhi 29: 354-358, 2000 (In Chinese).

32. Zhang Z, Leonard SS, Huang C, Vallyathan V, Castranova V and Shi X: Role of reactive oxygen species and MAPKs in vanadate-induced G(2)/M phase arrest. Free Radic Biol Med 34: 1333-1042, 2003

33. Porter AG and Jänicke RU: Emerging roles of caspase-3 in apoptosis. Cell Death Differ 6: 99-104, 1999. 
34. Alvarez S, Drane P, Meiller A, Bras M, Deguin-Chambon V, Bouvard V and May E: A comprehens ive s tudy of p53 transcriptional activity in thymus and spleen of gamma irradiated mouse: High sens itivity of genes involved in the two main apoptotic pathways. Int J Radiat Biol 82: 761-770, 2006.

35. Raisova M, Hossini AM, Eberle J, Riebeling C, Wieder T, Sturm I, Daniel PT, Orfanos CE and Geilen CC: The Bax/Bcl-2 ratio determines the susceptibility of human melanoma cells to CD95/Fas-mediated apoptosis. J Invest Dermatol 117: 333-340, 2001.

36. Samarghandian S, Nezhad MA and Mohammadi G: Role of caspases, Bax and Bcl-2 in chrysin-induced apoptosis in the A549 human lung adenocarcinoma epithelial cells. Anticancer Agents Med Chem 14: 901-909, 2014.

37. Wong KK, Engelman JA and Cantley LC: Targeting the PI3K signaling pathway in cancer. Curr Opin Genet Dev 20: 87-90, 2010.
38. Rao E, Jiang C, Ji M, Huang X, Iqbal J, Lenz G, Wright G, Staudt LM, Zhao Y, McKeithan TW, et al: The miRNA-17 92 cluster mediates chemoresistance and enhances tumor growth in mantle cell lymphoma via PI3K/AKT pathway activation. Leukemia 26: 1064-1072, 2012.

39. Markman B, Dienstmann R and Tabernero J: Targeting the $\mathrm{PI} 3 \mathrm{~K} / \mathrm{Akt} / \mathrm{mTOR}$ pathway-beyond rapalogs. Oncotarget 1: 530-543, 2010.

40. Neri LM, Cani A, Martelli AM, Simioni C, Junghanss C, Tabellini G, Ricci F, Tazzari PL, Pagliaro P, McCubrey JA and Capitani S: Targeting the PI3K/Akt/mTOR signaling pathway in B-precursor acute lymphoblastic leukemia and its therapeutic potential. Leukemia 28: 739-748, 2014.

41. Slomovitz BM and Coleman RL: The PI3K/AKT/mTOR pathway as a therapeutic target in endometrial cancer. Clin Cancer Res 18 . 5856-5864, 2012. 